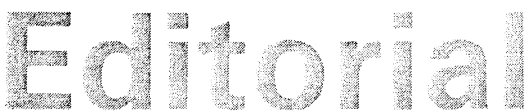

\section{The Cost of Tax Protection}

\author{
Barry Bracewell-Milnes, Banstead
}

Fifteen years ago who would have expected the large reductions in the top rates of income tax that have taken place over the last decade and a half? In the United Kingdom the top rate has been reduced from 98 per cent of gross income to 40 per cent, and there have been significant reductions in the top rates of most OECD countries. The original impulsion for these changes was ideological, the belief that very high rates of tax did more harm than good to the economy and even to the tax revenue; but the movement spread around the world through the influences of tax fashion and tax competition.

By contrast, the tax burden (total tax revenue as a proportion of national income) has over the last generation or more increased in most OECD countries and is at or near its historical peacetime highpoint. This increase over decades during which peace prevailed and prosperity increased shows that other forces were at work than the defence of the State and the relief of poverty.

Meanwhile competitiveness has been increasing, domestically and internationally. The business scene is changing more rapidly than ever before, not least because computers and electronics give the entrepreneur a much wider choice of where to engage in productive activity. The European Community is in competition with the United States and above all with the dynamic economies of the Far East, the Asian tigers. Tax burdens in these countries are 10 or 20 percentage points or even more below those in Europe. Taxes are costs and there has in consequence been a major shift of investment from Europe to the Far East at both corporate and individual levels. This competition for business acts as a constraint on tax raising in Europe and a cause of a shrinkage in the tax base. The late Professor Alan Prest has shown that it is inconsistent to assert both that indirect taxes are passed forwards (to the consumer) and that direct taxes are passed backwards (to the producer or saver); in particular, recent evidence suggests that taxes on internationally mobile capital fall on the borrower rather than the lender.

In the face of these developments, the reaction of the European Union and the OECD has been defensive. In the EU the UK Chancellor of the Exchequer, Nigel Lawson, was a lone voice in favour of tax competition; and since his departure, the waters have closed over. The OECD Committee on Fiscal Affairs has a Working Party Number 8 whose remit includes the discouragement or suppression of tax competition (fiscs of the world, unite). The cost of such tax protection can be illustrated by the European Commission's proposal of some twenty years ago to harmonise rates of corporation tax within a band of $45-55$ per cent: if this proposal had been adopted, many recent reductions in the rate of corporation tax, including the UK reduction to 33 per cent, would have been impossible and the high-tax regime of the 1970s would have been made permanent. Fiscally based competitive disadvantages require protection through barriers to trade, and an effective cartel between the tax authorities in the European Union would risk the division of the world into the three trading blocs prophetically described by George Orwell in '1984'. In the less likely event of similar cooperation between the countries of an enlarged OECD including Korea and other countries not at present members, the competitive advantage would be confined to a limited number of Asian tigers and other non-OECD members.

Protectionism and lower taxation are thus alternatives. Free trade exerts pressure on taxes as on other costs; if taxes are relieved of these pressures, restrictions on trade are a natural consequence. Cartels of tax authorities impose a cost on the economy, as do cartels in the production of goods and services; and tax cartels are more harmful than commercial cartels, because they are imposed by force and therefore more durable. The cost of tax protection is thus the reduction of prosperity caused by the distortion of economic activity inside the affected area and by the reduction of trade with outsiders. Tax protection is a continuing danger within the European Union. 